\title{
Utilization of ${ }^{14} \mathrm{C}$ formaldehyde to infer ingestion rates and absorption efficiencies by benthic deposit-feeders
}

\author{
François Charles*, Antoine Grémare, Jean Michel Amouroux \\ Laboratoire Arago, URA CNRS no. 117, Université Pierre et Marie Curie, F-66650 Banyuls-sur-Mer, France
}

\begin{abstract}
Several experiments were carried out to provide new information on the use of the ${ }^{14} \mathrm{C}$ formaldehyde technique in deposit-feeding studies. Our results show that: (1) uptake and stability of labelling vary with species and types of detritus, (2) there are significant differences between the labelling stabilities of uniformly and ${ }^{14} \mathrm{C}$ formaldehyde labelled diatoms. (3) the use of uniformly and ${ }^{14} \mathrm{C}$ formaldehyde labelled detritus derived from Pavlova lutheri results in very similar ingestion rates and absorption efficiencies by Abra ovata, (4) ingestion rates and absorption efficiencies of Abra ovata fed on 11 macrophytobenthic types of detritus labelled with ${ }^{14} \mathrm{C}$ formaldehyde are consistent with the literature (negative relationship between ingestion and protein content, and between absorption and phenolic content), and (5) absorption efficiencies recorded for ${ }^{14} \mathrm{C}$ formaldehyde labelled sediment trap materials collected at different periods of the year correlate negatively with gross sedimentation rates. These results support the use of the ${ }^{14} \mathrm{C}$ formaldehyde technique with monospecific detritus. The relative values of absorption efficiencies recorded for heterogeneous detritus also seem consistent. However, it is stressed that the exactitude of the absolute values of these absorption efficiencies is yet to be proven.
\end{abstract}

KEY WORDS: Radiotracer techniques - Sedimentary organic matter - Absorption efficiency - Depositfeeder $\cdot{ }^{14} \mathrm{C}$ formaldehyde

\section{INTRODUCTION}

As mentioned by Lopez et al. (1989), there are 2 specific assumptions for the use of radiotracers in assessing ingestion of organic matter: (1) the radiotracer must be associated to the organic but not to the inorganic fraction, and (2) the tested animal must not select organic matter according to specific activity. When assessing the absorption of sedimentary organic matter, the assumption of labelling uniformity supersedes nonselectivity assumptions.

These assumptions are usually supposed to be met when assessing utilization rates of live microorganisms which quickly incorporate radiolabelled substrates. However, the situation is much more delicate when one considers the utilization rates of complex detritus or naturally available sedimentary organic matter to which these labelling techniques are not transferable

\footnotetext{
•E-mail: charles@oob-arago.univ-perp.fr
}

This is why several protocols have been proposed to label detritus or sedimentary organic matter by chemical reaction with specific radioactive compounds such as acetic anhydride (Banks \& Wolfinbarger 1981), dimethyl sulfate (Wolfinbarger \& Crosby 1983, Crosby 1985), and formaldehyde (Lopez \& Crenshaw 1982). Among these methods, the one involving formaldehyde has been the most extensively used so far (Lopez \& Cheng 1982, 1983, Bricelj \& Malouf 1984, Lopez \& Elmgren 1989, Cheng \& Lopez 1991, Charles 1993).

The use of ${ }^{14} \mathrm{C}$ formaldehyde to study the utilization of sedimentary organic matter by benthic depositfeeders was first introduced by Lopez \& Crenshaw (1982) in order to provide a radiotracer technique that is specific for organic matter in sediment but nonspecific for different types of organic matter (Lopez et al. 1989). The labelling protocol involves the incubation of organic matter in the presence of ${ }^{14} \mathrm{C}$ formaldehyde in a hypersaline solution (i.e. $30 \% \mathrm{NaCl}$ ) which reversibly inhibits microbial activity (Lopez \& Cren- 
shaw 1982). The uptake of label is clearly due to chemical reactions with sedimentary organic matter (Lopez \& Crenshaw 1982). Thus the first of the 2 assumptions required for assessing ingestion and absorption rates seems to be met in the case of this particular radiolabelling method. The situation is less clear for the second hypothesis. Lopez et al. (1989) used the dual tracer (i.e. ${ }^{14} \mathrm{C}$ and ${ }^{51} \mathrm{Cr}$ ) method initially developed by Calow \& Fletcher (1972) to compare the absorption efficiencies of Hydrobia totteni and Mytilus edulis fed on uniformly and formaldehyde labelled algae and algal detritus. They found very similar absorption efficiencies by using the $2{ }^{14} \mathrm{C}$ labelling techniques and, on this basis concluded that the uniformity assumption should not be rejected. However, these authors also reported significant differences in absorption efficiencies of natural sedimentary organic matter measured by using either the ash ratio or the dual tracer method.

To a certain extent, these differences may be due to the existence of selectivity of ingestion relative to organic matter. However, another possible explanation to account for this heterogeneity is that the tests carried out for homogeneous substrates (such as microalgae) are not transferable to highly heterogeneous sedimentary organics. The aim of the present study was thus to provide new information on the interactions between ${ }^{14} \mathrm{C}$ formaldehyde and organic matter.

\section{MATERIALS AND METHODS}

Experiment 1: Label uptake. This experiment was designed to test the ability of ${ }^{14} \mathrm{C}$ formaldehyde to label substrates of different origins. Triplicates of $10 \mathrm{mg}$ ashfree dry weight (AFDW) of detritus freshly derived from 11 macrophytes (Corallina elongata, Rissoella verruculosa, Cystoseira compressa, Cystoseira mediterranea, Colpomenia sinuosa, Dilophus spiralis, Padina pavonica, Stypocolon scoparium, Codium vermilara, Ulva rigida, and Posidonia oceanica), 3 microphytes (Nitzschia acicularis, Nitzschia sp. and Pavlova lutheri), and materials collected on 4 different dates (4 August 1992, 29 September 1992, 19 January 1993, and 2 March 1993) in sediment traps located in the bay of Banyuls-sur-mer, France, were labelled with $11.5 \mu \mathrm{Ci}$ of ${ }^{14} \mathrm{C}$ formaldehyde. Fresh materials were frozen and freeze-dried. In addition, macrophytobenthic detritus was ground to a size smaller than $200 \mu \mathrm{m}$. All detritus was first washed in filtered $(0.2 \mu \mathrm{m})$ seawater for $3 \mathrm{~h}$. The labelling protocol was derived from the one proposed by Lopez \& Crenshaw (1982). The main differences were: (1) the duration of the incubation $(48$ vs 36 to $44 \mathrm{~h}$ ), (2) the number of rinses with seawater ( 3 vs 1), and (3) preincubation of $3 \mathrm{~h}$ in filtered seawater followed by centrifugation to remove any leached label (Charles 1993). All these changes aimed at improving the stability of the label. At the end of this procedure, samples were filtered on a $0.2 \mu \mathrm{m}$ Nuclepore membrane which was then hydrolyzed in hot $\mathrm{NaOH}$ ( $1 \mathrm{~N}$ at $60^{\circ} \mathrm{C}$ for $24 \mathrm{~h}$ ). Activities of ${ }^{14} \mathrm{C}$ corresponding to particulate organic matter (POM) were determined by liquid scintillation countings carried out on two $250 \mu \mathrm{l}$ subsamples of the hydrolyzates. There was no blank to correct for retention of formaldehyde on membranes since the amount of radioactivity adsorbed on membranes, if not negligible, depends on the amount of radioactivity (i.e. ${ }^{14} \mathrm{C}$ formaldehyde) within the dissolved organic matter (DOM) compartment.

Experiment 2: Relationship between uptake and stability of labelling. This experiment was designed to assess the relationship between labelling efficiency and labelling stability. Duplicated samples (10 $\mathrm{mg}$ AFDW of the 18 types of detritus used during the first experiment were radiolabelled with $11.5 \mu \mathrm{Ci}$ following the same protocol as in Expt 1. The detritus was then incubated for $48 \mathrm{~h}$ within aerated experimental chambers containing $300 \mathrm{ml}$ of filtered $(0.2 \mu \mathrm{m})$ seawater. At the end of the experiment, the radioactivity corresponding to $\mathrm{POM}, \mathrm{DOM}$ and $\mathrm{CO}_{2}$ was measured. The separation of POM and DOM was operational (filtration on a $0.2 \mu \mathrm{m}$ membrane) (see Charles 1993 for details of the procedure). The relationship between label uptake and labelling stability was assessed using a simple linear regression model.

Experiment 3: Comparison of labelling stability for detritus derived from uniformly and ${ }^{14} \mathrm{C}$ iormaldehyde radiolabelled microalgae. This experiment was carried out to compare changes in the partitioning of radioactivity of fresh detritus incubated alone in seawater when either uniformly or ${ }^{14} \mathrm{C}$ formaldehyde labelled. Duplicate samples of $10 \mathrm{mg}$ AFDW of fresh detritus derived from the 3 tested microphytes (Nitzschia acicularis, Nitzschia sp. and Pavlova lutheri) were either uniformly $(48 \mathrm{~h}$ incubation in the presence of ${ }^{14} \mathrm{C}$ sodium bicarbonate during the end of the exponential growth phase of the live monospecific cultures) or ${ }^{14} \mathrm{C}$ formaldehyde (same protocol as in Expt 1) labelled. Detritus was then incubated in experimental chambers containing $300 \mathrm{ml}$ of filtered $(0.2 \mu \mathrm{m})$ seawater for $4,10,20$ and $48 \mathrm{~h}$. At the end of each experiment, radioactivity was measured in POM, DOM and $\mathrm{CO}_{2}$ (see Charles 1993 for details of the procedure).

Experiment 4: Comparison of ingestion rates and absorption efficiencies obtained by the $2{ }^{14} \mathrm{C}$ labelling techniques. We conducted this set of experiments in order to compare the ingestion and absorption of uni- 
formly and formaldehyde labelled detritus freshly derived from Pavlova Iutheri by the deposit-feeding bivalve Abra ovata. Uniformly labelled detritus was prepared by growing an algal culture for $2 \mathrm{~d}$ (end of the exponential phase) with $10 \mu \mathrm{Ci}{ }^{14} \mathrm{C}$ sodium bicarbonate $\mathrm{l}^{-1}$ Similar, but unlabelled, cultures were grown as well. Cells from both cultures were harvested by centrifugation, frozen and freeze-dried. Detritus derived from the unlabelled cultures was then labelled with ${ }^{14} \mathrm{C}$ formaldehyde (same protocol as in Expt 1). It is important to point out that uniformly labelled detritus was submitted to the same sequence of rinses (i.e. both in seawater and in $30 \% \mathrm{NaCl}$ ) as ${ }^{14} \mathrm{C}$ formaldehyde labelled detritus.

The experimental approach used to assess ingestion and absorption was identical to the one used by Charles (1993). It associated compartmental analysis and analog modelling (Grémare et al. 1991). Compartmental analysis consisted of the measurement of the temporal changes of the distribution of radioactivity between the different compartments (i.e. POM, $\mathrm{CO}_{2}, \mathrm{DOM}$, and bivalves) of a closed system. The analytical procedure used to quantify radioactivity within these 4 compartments is detailed in Charles (1993). Modelling allowed for computation of radioactivity transfers between compartments. The model was almost identical to the one used by Charles (1993). Its structure can be found in Charles (1994) and in Charles et al. (1994). Ingestion rates and absorption efficiencies were computed based on the values of the kinetic coefficients of the fitted models as proposed by Charles (1993). Briefly, the computation of ingestion rates was based on the cumulative amount of radioactivity corresponding to the transfer between detritus and bivalves. There are 3 different ways to estimate absorption. The first is based on the cumulative amounts of radioactivity produced as DOM and $\mathrm{CO}_{2}$ by the bivalves; it leads to an underestimation of absorption. The second is based on the cumulative amount of radioactivity produced as faeces by the bivalves; it leads to an overestimation of absorption. The third is based on the ratio between kinetic coefficients controlling the production of DOM and $\mathrm{CO}_{2}$ and the kinetic coefficient controlling the production of faeces. It constitutes a direct estimation of absorption.

Experiment 5: Utilization of detritus derived from macrophytes. This experiment was designed to test the consistency of ingestion rates and absorption efficiencies obtained with the formaldehyde method relative to the existing literature regarding the control of ingestion and absorption of benthic invertebrates. Fresh detritus was prepared from 11 macrophytes and labelled with ${ }^{14} \mathrm{C}$ formaldehyde (same macrophytes and protocol as in Expt 1). This detritus was then used to assess ingestion rates and absorption efficiencies of the deposit-feeding bivalve Abra ovata. Compartmental analysis and analog modelling were strictly identical to that used by Charles (1993), and can also be found in Charles (1994) or Charles et al. (in press). The relationships between the main biochemical characteristics (water content, \% organics, caloric content, protein, carbohydrate, and total phenolics) of the tested detritus and ingestion and absorption were assessed by using a principal component analysis (Frantzis \& Grémare 1992).

Experiment 6: utilization of detritus derived from sediment traps. This experiment was designed to test the use of ${ }^{14} \mathrm{C}$ formaldehyde to assess temporal changes in the utilization rates of sediment trap collected materials by the deposit-feeding bivalve Abra ovata. Sediment trap materials were collected in the bay of Banyuls-sur-mer on 4 different dates (4 August 1992, 29 September 1992, 19 January 1993 and 2 March 1993). They were then freeze-dried and labelled with ${ }^{14} \mathrm{C}$ formaldehyde (same station, dates, and protocol as in Expt 1). This detritus was then used to assess ingestion and absorption of the deposit-feeding bivalve Abra ovata. Compartmental analysis was identical to those used during Expts $4 \& 5$. The structure of the model can be found in Charles (1994) and in Charles et al. (1995). Ingestion rates and absorption efficiencies were computed as proposed by Charles (1993).

\section{RESULTS}

\section{Experiment 1}

The amount of ${ }^{14} \mathrm{C}$ formaldehyde incorporated into the detritus was significantly affected by the origin of the considered detritus (Kruskall-Wallis 1-way ANOVA, $p<0.001$ ) (cf. Fig. 1). The amount of incorporated label was between $0.4 \mu \mathrm{Ci}$ (detritus derived from Ulva rigida) and $6.1 \mu \mathrm{Ci}$ (detritus derived from Colpomenia sinuosa). The amount of incorporated label varied both among and within the 3 broad categories of tested detritus (i.e. macrophytes, microphytes, and sediment trap materials). The amounts of incorporated label were maximal for detritus derived from chromophytes and minimal for that derived from rhodophytes and chlorophytes (with the exception of that derived from the phanerogam Posidonia oceanica which exhibited a relatively high value). Detritus derived from microphytes and sediment trap materials showed intermediary incorporations. Regarding sediment trap materiais, incorporations of label were maximal during winter and minimal during spring. 


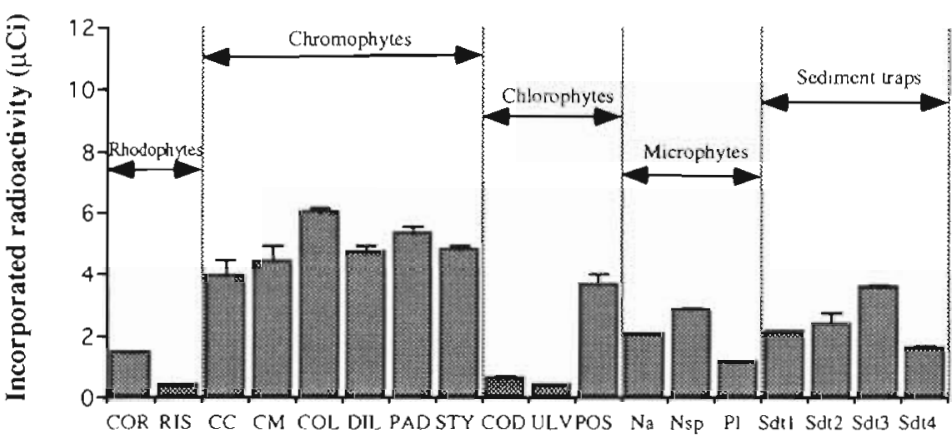

Detritus

Fig. 1 Expt 1 Amounts of ${ }^{14} \mathrm{C}$ formaldehyde incorporated by the 18 tested types of detritus. The labelling procedure was identical for all tested detritus (i.e. $10 \mathrm{mg} O \mathrm{OM}$ of detritus incubated in the presence of $11.5 \mu \mathrm{Ci}$ of ${ }^{14} \mathrm{C}$ formaldehyde). Vertical bars are standard deviations, COR: Corallina elongata, RIS: Rissoella verruculosa, CC: Cystoseira compressa, CM: Cystoseira mediterranea, COL: Colpomenia sinuosa, DIL: Dilophus spiralis, PAD: Padina pavonica, STY: Stypocaulon scoparium, COD: Codium vermilara, ULV: Ulva rigida, POS: Posidonia oceanica, Na: Nitzschia acicularis, Nsp: Nitzschia sp., Pl: Pavlova lutheri, Sdt1: sediment trap material collected on 4 August 1992, Sdt2: sediment trap material collected on 29 September 1992, Sdt3: sediment trap material collected on 19 January 1993, Sedt4: sediment trap material collected on 2 March 1993

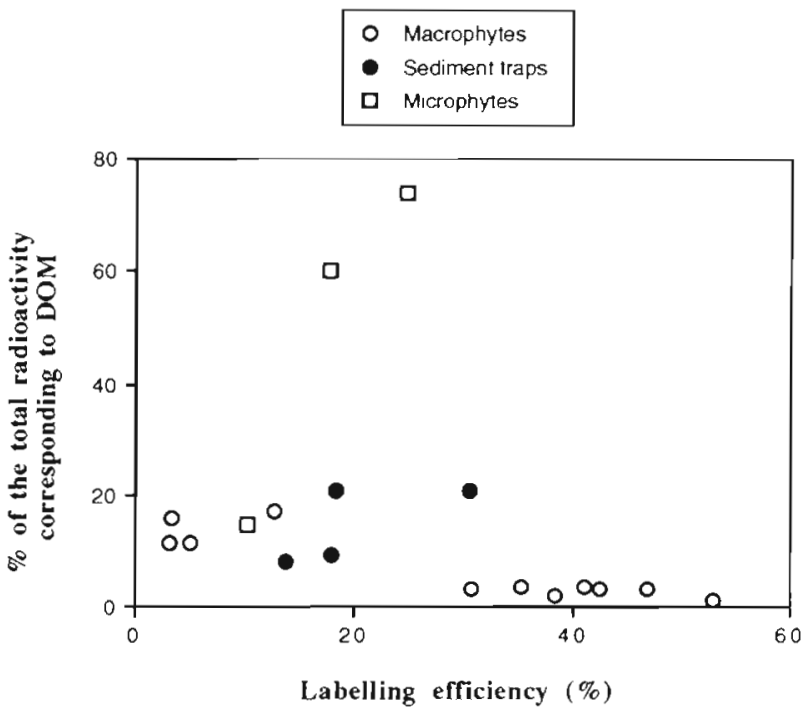

Fig. 2. Expt 2. Relationship between labelling efficiency and the proportion of radioactivity corresponding to DOM after $48 \mathrm{~h}$ within the controls. The latter variable is an index of labelling stability

\section{Experiment 2}

For all the tested detritus except that derived from Nitzschia acicularis $\left(\mathrm{CO}_{2}\right.$ corresponding to $8.9 \%$ of the total radioactivity after $48 \mathrm{~h}$ of incubation), the production of radioactive $\mathrm{CO}_{2}$ remained negligible (i.e. less than $1.4 \%$ of the total radioactivity after $48 \mathrm{~h}$ of incubation). Thus, the main exchange of radioactivity occurred between POM and DOM. The relationship between labelling efficiency (defined as the proportion of the radioactivity introduced at the beginning of the labelling procedure which is adsorbed to the detritus) and the \% of the total radioactivity corresponding to DOM after $48 \mathrm{~h}$ of incubation is presented in Fig. 2. The detritus derived from the 2 diatoms differed clearly from the other 16 types of detritus since it was characterized by a very important loss of radioactivity as DOM $(60.0$ and $73.7 \%$ of the total radioactivity after $48 \mathrm{~h}$ for the detritus derived from Nitzschia acicularis and Nitzschia sp., respectively). If these 2 data points are disregarded, there is a significant negative relationship between labelling efficiency and the amount of radioactivity lost as DOM ( $\mathrm{r}=-0.680, \mathrm{n}=16, \mathrm{p}<0.001)$. The significance of this relationship is mostly due to the detritus derived from macrophy̧tes

\section{Experiment 3}

For both diatoms, there were significant differences in the temporal changes of the partitioning of radioactivity between detritus labelled with the $2{ }^{14} \mathrm{C}$ techniques (cf. Fig. 3). The loss of radioactivity as DOM was much more important when ${ }^{14} \mathrm{C}$ formaldehyde was used. After $48 \mathrm{~h}$ of experimentation, the amount of radioactivity corresponding to DOM accounted for $59.9 \%$ of the total radioactivity (against only $7.3 \%$ in the case of uniform labelling) in experimental chambers containing detritus derived from Nitzschia acicularis, and for $73.7 \%$ of the total radioactivity (against only $9.7 \%$ in the case of uniform labelling) in the experimental chambers containing detritus derived from Nitzschia sp. This difference was much less important for the detritus derived from Pavlova lutheri (DOM accounting for $14.8 \%$ of the total radioactivity after $48 \mathrm{~h}$ of incubation for ${ }^{14} \mathrm{C}$ labelled detritus, against $8.9 \%$ for uniformly labelled detritus). Diatoms were not examined microscopically, however due to important differences in production of radioactive DOM by (1) uniformly and ${ }^{14} \mathrm{C}$ formaldehyde labelled algae, and (2) the $2{ }^{14} \mathrm{C}$ formaldehyde diatoms and ${ }^{14} \mathrm{C}$ formaldehyde Pavlova lutheri, it is likely that the bulk of the release of radioactive DOM does not correspond to the physical breakdown of phytoplanktonic cells. 
Nitzschia acicularis

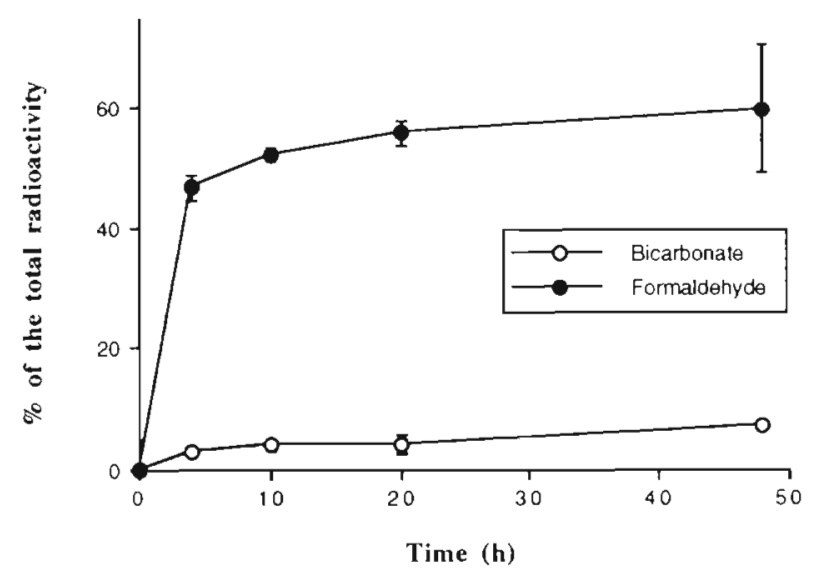

Nitzschia sp.

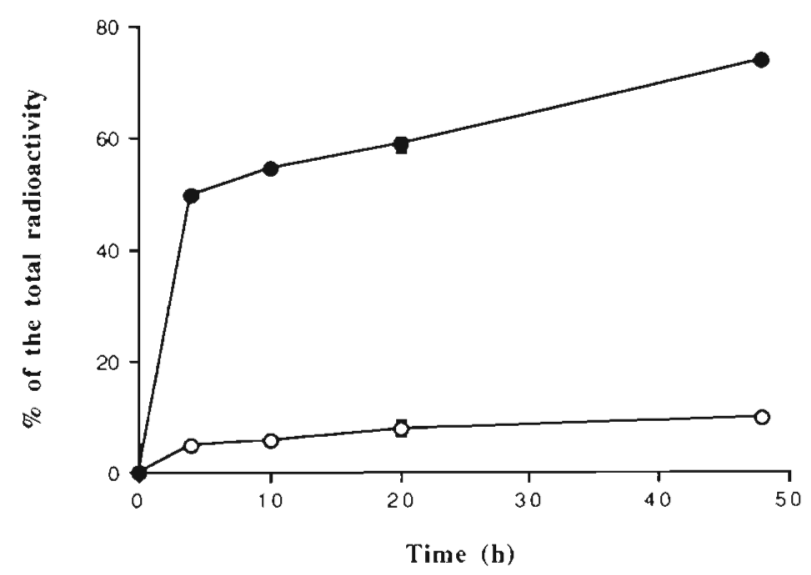

Pavlova lutheri

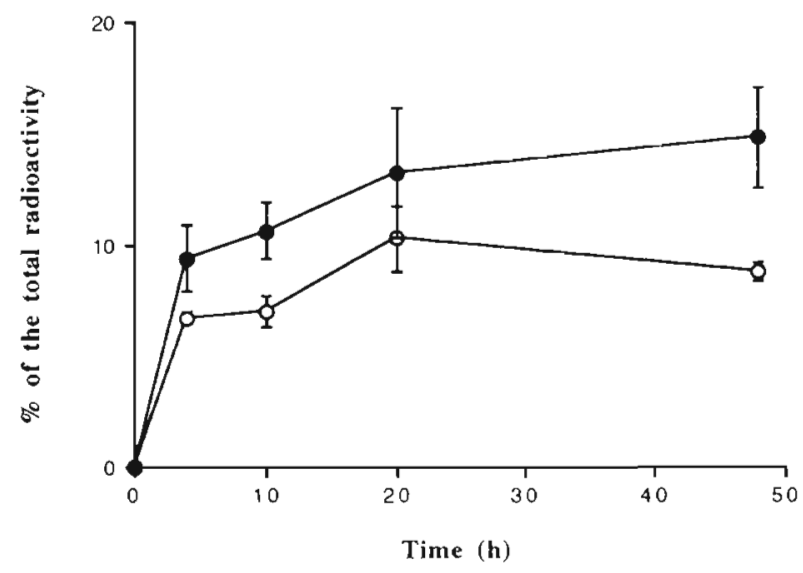

Fig. 3. Temporal changes in the proportion of total radio activity corresponding to DOM within experimental chambers containing detritus derived from uniformly $\left({ }^{14} \mathrm{C}\right.$ bicarbonate) or ${ }^{14} \mathrm{C}$ formaldehyde labelled microalgae. Vertical bars: $\mathrm{SD}$

\section{Experiment 4}

Weight specific ingestion rates of Abra ovata fed on detritus freshly derived from Pavlova lutheri were estimated at $0.51 \times 10^{-3} \mathrm{mg} O M \mathrm{mg} \mathrm{DW}^{-1} \mathrm{~h}^{-1}$ for uniformly labelled detritus and at $0.53 \times 10^{-3} \mathrm{mg} \mathrm{OM} \mathrm{mg}$ $\mathrm{DW}^{-1} \mathrm{~h}^{-1}$ for formaldehyde labelled detritus (cf. Table 1). Corresponding absorption efficiencies ranged between 13 and $24 \%$ (uniformly labelled detritus) versus 16 and $21 \%$ (formaldehyde labelled detritus). There was a good agreement between the direct estimations of absorption efficiencies $17 \%$ for uniformly labelled detritus vs $18 \%$ for formaldehyde labelled detritus; cf. Table 1).

\section{Experiment 5}

The main characteristics of the tested detritus are presented in Table 2 together with corresponding ingestion rates and absorption efficiencies by Abra ovata. The ingestion rates of Abra ovata fed on the 11 tested types of detritus ranged between 0.16 (Cystoseira mediterranea and Dilophus spiralis) and $8.65 \times 10^{-3} \mathrm{mg}$ OM mg DW ${ }^{-1} \mathrm{~h}^{-1}$ (Ulva rigida). Direct estimations of absorption efficiencies ranged between $0.5 \%$ (detritus derived from Colpomenia sinuosa) and $12.1 \%$ (detritus derived from Corallina elongata). The results of the principal component analysis are presented in Fig. 4. The first 3 axes accounted respectively for $5.9,71.3$, and $7.9 \%$ of the variance of ingestion

Table 1. Expt 4. Kinetic coefficients, ingestion rates and different estimations of absorption efficiencies corresponding to the fitted models (see Charles 1993) obtained for detritus derived from uniformly $\left({ }^{14} \mathrm{C}\right.$ bicarbonate) and ${ }^{14} \mathrm{C}$ formaldehyde labelled Pavlova lutheri

\begin{tabular}{|lcc|}
\hline & Bicarbonate & Formaldehyde \\
\hline Kinetic coefficients $\left(\mathrm{h}^{-1}\right)$ & & \\
$K_{1}$ & 0.0095 & 0.0098 \\
$K_{2}$ & 0.3600 & 0.7000 \\
$K_{3}$ & 0.1300 & 0.3000 \\
$K_{4}$ & 0.0000 & 0.0000 \\
$K_{5}$ & 0.0000 & 0.0080 \\
$K_{6}$ & 0.0750 & 0.1500 \\
$K_{7}$ & 0.0000 & 0.0000 \\
$K_{8}$ & 0.0030 & 0.0010 \\
Ingestion (10-3 $\left.\mathrm{mg}^{-1} \mathrm{~h}^{-1}\right)$ & 0.51 & \\
OM mg DW & & 0.53 \\
Absorption (\%) & & \\
Underestimation & 13 & 16 \\
Overestimation & 24 & 21 \\
Direct estimation & 17 & 18 \\
\hline
\end{tabular}


Table 2. Expt 5. Main characteristics of the 11 tested types of detritus and corresponding estimations of ingestion and absorption by Abra ovata

\begin{tabular}{|c|c|c|c|c|c|c|c|c|}
\hline Macrophyte & $\begin{array}{l}\text { Water } \\
(\% \text { WW })\end{array}$ & $\begin{array}{c}\text { Organic } \\
\text { matter } \\
(\% \text { DW })\end{array}$ & $\begin{array}{c}\text { Energy } \\
(\mathrm{J} \mathrm{mg} \\
\left.\mathrm{DW} \mathrm{W}^{-l}\right)\end{array}$ & $\begin{array}{l}\text { Proteins } \\
\text { (\%DW) }\end{array}$ & $\begin{array}{l}\text { Carbo- } \\
\text { hydrates } \\
\text { (\%DW) }\end{array}$ & $\begin{array}{c}\text { Phenolics } \\
(\mathrm{mg} \mathrm{g} \\
\left.\mathrm{OM}^{-1}\right)\end{array}$ & $\begin{array}{c}\text { Ingestion } \\
\left(10^{-3} \mathrm{mg}\right. \\
\left.\mathrm{OM}^{-1} \mathrm{~h}^{-1}\right)\end{array}$ & $\begin{array}{c}\text { Absorption } \\
(\%)\end{array}$ \\
\hline Cystoseira mediterranea & 79.3 & 70.2 & 12.5 & 18.6 & 20.2 & 18.2 & 6.8 & 2.2 \\
\hline Dilophus spiralis & 81.0 & 70.3 & 14.3 & 19.0 & 16.6 & 3.4 & 2.6 & 1.4 \\
\hline Colpomenia sinuosa & 92.0 & 36.6 & 6.7 & 13.3 & 13.7 & 9.2 & 5.9 & 0.9 \\
\hline Cystoseira compressa & 82,9 & 65.1 & 10.3 & 20.8 & 15.2 & 53.0 & 3.8 & 2.0 \\
\hline Padina pavonica & 78.7 & 48.7 & 5.6 & 12.3 & 11.7 & 4.9 & 6.4 & 0.5 \\
\hline Posidonia oceanica & 76.4 & 78.4 & 14.8 & 12.4 & 33.6 & 24.0 & 0.2 & 10.0 \\
\hline Stypocaulon scoparium & 67.0 & 69.3 & 11.7 & 16.3 & 22.7 & 3.0 & 0.2 & 6.1 \\
\hline Codium vermilara & 91.9 & 50.5 & 9.0 & 9.6 & 27.7 & 1.1 & 3.2 & 6.5 \\
\hline Corallina elongata & 27.0 & 21.5 & 2.3 & 4.6 & 5.1 & 2.4 & 8.1 & 9.1 \\
\hline Rissoella verruculosa & 70.9 & 78.7 & 13.7 & 12.4 & 41.7 & 9.8 & 3.2 & 11.4 \\
\hline Ulva rigida & 78.7 & 68.5 & 10.2 & 6.5 & 37.0 & 1.0 & 3.2 & 6.3 \\
\hline
\end{tabular}
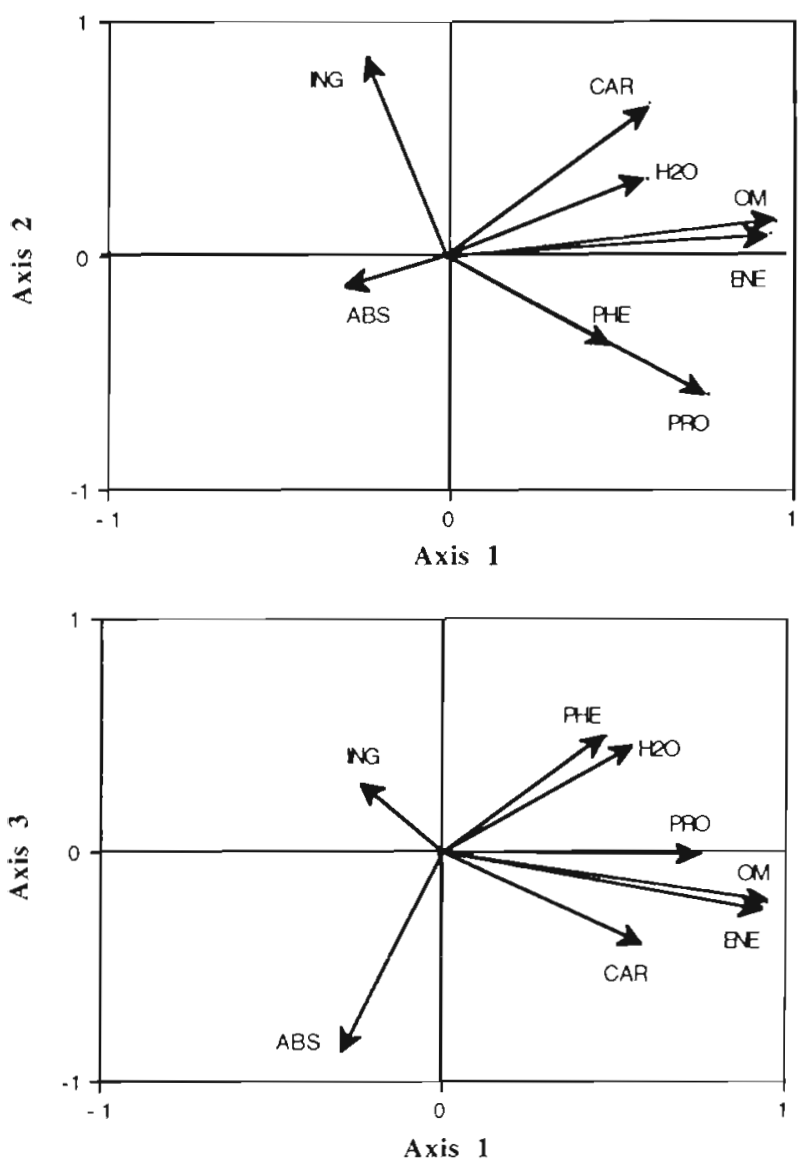

Fig. 4. Expt 5. Principal component analysis based on the values of the following parameters: ingestion (ING), absorption (ABS), water content $\left(\mathrm{H}_{2} \mathrm{O}\right)$ \% organic matter (OM), caloric content (ENE), protein (PRO), carbohydrate (CAR), and total phenolics (PHE). Graphs show the positions of the descriptors on Axes 1 \& 2 (top), and on Axes 1 \& 3 (bottom) rates, and for 9.1, 1.7 and $75.6 \%$ of the variance of absorption efficiencies. The second axis was characterized by the opposition between ingestion rates and protein and phenolic content. The third axis was characterized by the opposition between absorption efficiencies and phenolic content.

\section{Experiment 6}

Gross sedimentation rates, weight specific ingestion rates and absorption efficiencies of Abra ovata are presented in Table 3 together with the organic, carbon, nitrogen and protein contents of the sediment trap derived detritus. When expressed in terms of organic matter (OM), ingestion rates were almost constant, between 3.5 (material collected on 29 September 1992) and $4.9 \times 10^{-3} \mathrm{mg} O M \mathrm{mg} \mathrm{DW} \mathrm{DW}^{-1} \mathrm{~h}^{-1}$ (material collected on 19 January 1993). Direct estimations of absorption efficiencies were between 6.4 (material collected on 29 September 1992) and $21.0 \%$ (material collected on 4 August 1992).

\section{DISCUSSION AND CONCLUSIONS}

\section{Preparation of detritus}

Degradation of plant detritus shows different stages. The first step corresponds to a rapid loss of soluble and lysable organics, which may be confusing in depositfeeding studies. It is thus essential to know how artificial detritus is prepared before discussing results of experiments assessing labelling uptake and stability or utilization rates by benthic invertebrates. The detritus used during the present study was prepared from freeze-dried material, and was thoroughly washed 
Table 3. Expt 6. Gross sedimentation rates, main characteristics of sediment trap derived detritus and corresponding estimations of ingestion and absorption by Abra ovata

\begin{tabular}{|c|c|c|c|c|c|c|c|}
\hline Date & $\begin{array}{c}\text { Gross } \\
\text { sedimentation } \\
\left(g \mathrm{DW} \mathrm{m}^{-2} \mathrm{~d}^{-1}\right)\end{array}$ & $\begin{array}{l}\text { Organic } \\
\text { matter } \\
\text { (\%DW) }\end{array}$ & $\begin{array}{l}\text { Carbon } \\
(\% D W)\end{array}$ & $\begin{array}{c}\text { Nitrogen } \\
(\% \mathrm{DW})\end{array}$ & $\begin{array}{l}\text { Proteins } \\
\text { (\%DW) }\end{array}$ & $\begin{array}{c}\text { lngestion } \\
\left(10^{-3} \mathrm{mg} \mathrm{OM}\right. \\
\left.\mu g \mathrm{mg} \mathrm{DW}^{-1}\right)\end{array}$ & $\begin{array}{c}\text { Absorption } \\
\left(\begin{array}{c}\text { mg OM } \\
\left.h^{-1}\right)\end{array}\right.\end{array}$ \\
\hline 4 Aug 1992 & 1.6 & 21.1 & 8.4 & 0.74 & 20.3 & 4.0 & 21.0 \\
\hline 29 Sep 1992 & 108.0 & 8.0 & 4.9 & 0.41 & 7.1 & 3.5 & 6.4 \\
\hline $19 \mathrm{Jan} 1993$ & 3.1 & 11.1 & 4.7 & 0.44 & 7.3 & 4.9 & 16.2 \\
\hline 2 Mar 1993 & 102.6 & 6.4 & 2.4 & 0.12 & 1.9 & 4.0 & 10.1 \\
\hline
\end{tabular}

several times before each experiment (cf. 'Materials and Methods'). In addition, we point out that: (1) we modified the procedure initially proposed by Lopez \& Crenshaw (1982) in order to reduce leaching of DOM, and (2) leaching experiments carried out on several types of detritus derived from freeze-dried material have shown that the loss of hydrosoluble molecules occurs during the very first minutes of immersion (Grémare et al. 1989). We are thus confident in stating that the results presented here do not correspond to an artefact due to the leaching of soluble and lysable organics.

\section{Labelling homogeneity (Expt 1)}

Although formaldehyde reacts with a wide variety of functional groups (Lopez \& Crenshaw 1982), there is no a priori evidence that it results in a homogeneous labelling of sedimentary organics (Lopez et al. 1989). Our own results indeed suggest that the efficiency of the labelling procedure is dependent on the type of detritus. Moreover, such differences are related to the origin of the detritus (i.e. maximal for chromophytes, intermediary for microphytes and sediment trap materials, and minimal for chromophytes and chlorophytes). Thus differences in labelling efficiencies probably result from differences in the reactivity of ${ }^{14} \mathrm{C}$ formaldehyde with various chemical compounds. This may cause a serious problem when using ${ }^{14} \mathrm{C}$ formaldehyde to label natural (i.e. heterogeneous) detritus.

\section{Labelling stability (Expts 2 \& 3)}

Results of the present study clearly show that the stability of the label depends on the origin of detritus. Here again, this may cause a serious problem when using ${ }^{14} \mathrm{C}$ formaldehyde to label natural detritus.

The detritus derived from the 2 tested diatoms was characterized by a very high instability of the label. This result is probably not due to mucus since (1) the reactivity of formaldehyde is much lower for polysaccharids than for proteins (Pottu-Boumendil 1989), and
(2) labelling efficiencies are much higher for diatom derived detritus than for detritus derived from Codium vermilara (i.e. the macrophyte which exhibits the highest mucus concentration; J. M. Amouroux pers. obs.), and there is no important loss of radioactivity for the detritus derived from Codium vermilara (11.3\% of total radioactivity after $48 \mathrm{~h}$ of incubation). Another hypothesis which may account for this instability is linked with one of the specific actions of formaldehyde on diatoms. Indeed, formaldehyde appears to accelerate the erosion of fine pore occlusions (Round et al. 1990) which may account for the leaching of cytoplasmic labelled material. It would be very interesting to further test this hypothesis by assessing the stability of the label in uniformly labelled diatoms incubated in the presence of nonradioactive formaldehyde $(\mathrm{NaCl} 30 \%$, $48 \mathrm{~h}$ ).

If one excepts the case of the 2 tested diatoms, there is a negative relationship between labelling efficiency and the amount of radioactivity lost as DOM. Two different pathways may account for the loss of radioactive DOM: (1) leaching of soluble organics (i.e. bound with ${ }^{14} \mathrm{C}$ formaldehyde), and (2) desorption of ${ }^{14} \mathrm{C}$ formaldehyde in itself. Because of the way detritus was prepared (see the first section of 'Discussion'), we do not believe that the bulk of the production of radioactive DOM is due to leaching Thus, most of the radioactive DOM probably corresponds to desorbed formaldehyde. In any case, control experiments are essential when assessing the effects of the labelling procedure on the measure of ingestion and absorption (such as in Lopez et al. 1989). During the present study, the control experiments led us to limit this comparison to the detritus derived from Pavlova lutheri (for which labelling stability was almost equivalent for formaldehyde and uniformly labelled detritus).

\section{Utilization of ${ }^{14} \mathrm{C}$ formaldehyde with homogeneous detritus (Expts 4 \& 5)}

Two lines of evidence suggest that ${ }^{14} \mathrm{C}$ formaldehyde can be used to label homogeneous detritus: (1) the 
comparison of ingestion rates and absorption efficiencies of formaldehyde and uniformly labelled detritus derived from Pavlova lutheri, and (2) the nature of the relationships linking the main characteristics of the detritus derived from the 11 tested macrophytes and the levels of utilization of this detritus by Abra ovata.

Comparison of ingestion rates and absorption efficiencies obtained with the 2 labelling techniques constitutes a direct test of the adequacy of the ${ }^{14} \mathrm{C}$ formaldehyde labelling technique. This adequacy was already positively assessed by Lopez et al. (1989) for Mytilus edulis and Hydrobia totteni fed on different types of detritus derived from Isochrysis $\mathrm{sp}$. Results from the present study also reveal a good agreement between ingestion rates and absorption efficiencies obtained with the 2 labelling techniques. The main difference between our study and the one carried out by Lopez et al. (1989) is that their measure of absorption was based on the dual tracer method (i.e. on the sole assumption that ${ }^{14} \mathrm{C}$ formaldehyde passes the gut wall at the same rate as non-labelled carbon), whereas our approach (chase experiments) required similar assumptions on the production of DOM and $\mathrm{CO}_{2}$ by bivalves. The results of the present study constitute thus the first validation of the use of the ${ }^{14} \mathrm{C}$ formaldehyde technique for this particular experimental approach.

The principal component analysis based on the main characteristics of the macrophytobenthic detritus and its utilization rates by Abra ovata shows the opposition between: (1) ingestion rates and phenolic and protein contents, and (2) absorption efficiencies and phenolic contents. Both of these results are in good agreement with the literature. The opposition between ingestion rates and protein contents supports the negative correlation between ingestion rates and food contents usually found at relatively high levels of organic contents (Cammen 1980, Phillips 1984, Taghon \& Greene 1990). The negative relationship between ingestion rates and phenolic contents was already reported in the case of benthic herbivores (Steinberg 1988). Moreover, the opposition between absorption efficiencies and phenolics is consistent with the reduction of the activity of digestive enzymes by phenolics (Tugwell \& Branch 1992). Such a consistency tends to provide a second line of evidence of the adequacy of the use of the ${ }^{14} \mathrm{C}$ formaldehyde technique in the case of homogeneous detritus. However, it should be stressed that this approach is only indirect and that some of the patterns found in the principal component analysis may also result from co-correlation. For example, the opposition between absorption and phenolic content may only reflect the high labelling efficiencies and phenolic contents characterizing detritus derived from brown algae.

Thus our overall conclusion is that this technique is probably appropriate to assess ingestion rates and absorption efficiencies of most monospecific detritus. However, the present study also emphasizes the importance of carrying out preliminary experiments assessing the stability of the label, since it revealed a total lack of stability of the label for the detritus derived from diatoms.

\section{Utilization of ${ }^{14} \mathrm{C}$ formaldehyde with heterogeneous detritus (Expt 6)}

It is not presently possible to assess directly the adequacy of the ${ }^{14} \mathrm{C}$ formaldehyde technique for heterogeneous detritus since there is no labelling procedure insuring a homogeneous label of sedimentary organics. In fact, at present, direct labelling techniques constitute the only possible way to assess absorption efficiencies of heterogeneous detritus. The only lines of evidence that can be collected are thus indirect. This situation is why we decided to compare ingestion rates and absorption efficiencies of sediment trap materials collected at different periods of the year. There were significant differences (i.e. between 6.4 and $21.1 \%$ of DW) in the organic contents of sediment trap materials collected on the 4 test dates. Thus, the relative constancy of ingestion rates (when expressed in terms of organic matter) supported the existence of a mechanism of compensatory intake in Abra ovata, since ingestion of organic matter tends to stay constant when food organic content changes. Moreover, at the studied station there is a negative correlation between gross sedimentation rates and organic contents of sediment trap materials [see Table 3 or Charles (1994) and Charles et al. (1995) for more complete data]. Such a pattern is mainly due to resuspension of sediment cued by the wind (Charles 1994, Charles et al. 1995). The comparison of the absorption efficiencies recorded during the present study shows that: (1) when gross sedimentation is minimal, absorption efficiency is higher for material collected during summer than during winter ( 21.0 vs $16.2 \%$ ), and (2) during fall and winter, high absorption efficiencies are related to low gross sedimentation (16.2 vs 10.1 and $6.4 \%$ ). These results are consistent with the dilution of the material directly sedimenting from the water column with resuspended (and supposedly more refractory) sediment. These results thus contribute to providing indirect evidence supporting the use of ${ }^{14} \mathrm{C}$ formaldehyde with heterogeneous detritus. However, it should be stressed that the present section of the discussion is solely based on the relative values of absorption, and thus does not constitute a proof of the exactitude of the absolute values of these absorption efficiencies, which is yet to be demonstrated. 
Acknowledgements. This work was partly funded through the 'Programme National d'Océanographie Cótière'

\section{LITERATURE CITED}

Banks CW, Wolfinbarger L Jr (1981) A rapid and convenient method for radiolabelling detritus with ${ }^{14} \mathrm{C}$ acetic anhydride. J exp mar Biol Ecol 53:115-123

Bricelj VM, Malouf RE (1984) Influence of algal and suspended sediment concentrations on the feeding physiology of the hard clam Mercenaria mercendria. Mar Biol 84: $155-165$

Calow P, Fletcher CR (1972) A new radiotracer technique involving ${ }^{14} \mathrm{C}$ and ${ }^{3 i} \mathrm{Cr}$ for estimating the assimilation efficiencies of aquatic primary consumers. Oecologia 9:156-170

Cammen LM (1980) Ingestion rate: an empirical model for aquatic deposit-feeders and detritivores. Oecologia 40 : $303-310$

Charles F (1993) Utilization of fresh detritus derived from Cystoseira mediterranea and Posidonia oceanica by the deposit-feeding bivalve Abra ovata. J exp mar Biol Ecol $174: 43-64$

Charles F (1994) Etude expérimentale du niveau d'utilisa-tion de matériel détritique d'origines différentes par le bivalve dépositivore Abra ovata. PhD thesis, University of Paris VI

Charles F, Amouroux JM, Grémare A (1994) Etude expérimentale des niveaux d'utilisation des détritus dérivés de 3 microphytes par le bivalve Abra ovata (Philippi). Oceanol Acta

Charles F, Grémare A, Amouroux JM (in press) Ingestion rates and absorption efficiencies of Abra ovata (Mollusca: Bivalvia) fed on macrophytobenthic detritus. Estuar coast Shelf $\mathrm{Sci}$

Charles F, Grémare A, Amouroux JM, Baudart J (1995) A bioassay approach to temporal variation in the nutritional value of sediment trap material. J exp mar Biol Ecol 191 $65-82$

Cheng IJ, Lopez GR (1991) Contribution of bacteria and sed1mentary organic matter to the diet of Nucula proxima, a deposit-feeding protobranchiatye bivalve. Ophelia 34: $157-170$

Crosby MP (1985) The use of a rapid radiolabelling method. for measuring ingestion rates of detritivores. J exp mar Biol Ecol 93:273-283

Frantzis A, Grémare A (1992) Ingestion, absorption, and growth rates of Paracentrotus lividus (Echinodermata: Echinoidea) fed different macrophytes. Mar Ecol Prog Ser 95:169-183

Grémare A, Amouroux JM, Charles F (1991) Compartmental analysis and analog modelling: a tool to study the con-

This article was presented by K. R. Tenore (Senior Editorial Advisor), Solomons, Maryland, USA sumption of organic matter by benthic invertebrates. In: Kershaw PJ, Woodhead DS (eds) Proceedings of the Radstomp '91. Elsevier Applied Sciences, London, p $319-328$

Grémare A, Marsh AG. Tenore KR (1989) Short-term reproductive responses of Capitella sp. I (Annelida: Polychaeta) fed on different diets. J exp mar Biol Ecol 123: $147-162$

Lopez GR, Cheng IJ (1982) Ingestion selectivity of sedimentary organic matter by the deposit-feeder Nucula annulata (Bivalvia: Nuculidae). Mar Ecol Prog Ser 8:279-282

Lopez GR, Cheng IJ (1983) Synoptic measurements of ingestion rate, ingestion selectivity, and absorption efficiency of natural foods in the deposit-feeding molluscs Nucula annulata (Bivalvia) and Hydrobia totteni (Gastropoda). Mar Ecol Prog Ser 11:55-62

Lopez GR, Crenshaw MA (1982) Radiolabelling of sedimentary organic matter with ${ }^{14} \mathrm{C}$-formaldehyde: preliminary evaluation of a new technique for use in deposit-feeding studies. Mar Ecol Prog Ser 8:283-289

Lopez GR, Elmgren R (1989) Feeding depths and organic absorption for the deposit-feeding benthic amphipods Pontoporeia affinis and Pontoporeia femorata. Limnol Oceanogr 34:982-991

Lopez GR, Tantichodok P, Cheng IJ (1989) Radiotracer methods for determining utilization of sedimentary organic matter by deposit-feeders. In: Lopez GR, Taghon GL, Levinton JS (eds) Ecology of marine deposit-feeders XIl. Springer Verlag, New York, p 149-170

Phillips NW (1984) Compensatory intake can be consistent with optimal foraging model. Am Nat 123:867-872

Pottu-Boumendil J (1989) Techniques en microscopie électronıque. Principes et méthodes de préparation. Editions INSERM, Paris, p 9

Round FE, Crawford RM, Mann DG (1990) The diatoms. Biology \& morphology of the genera. Cambridge University Press, Cambridge, p 12

Steinberg PD (1988) The effects of quantitative and qualitative variation in phenolic compounds on feeding in three species of marine herbivores. J exp mar Biol Ecol 120 : $221-237$

Taghon GL, Greene RR (1990) Effects of sediment-protein concentration on feeding and growth rates of Abarenicola pacifica Healy et Wells (Polychaeta: Arenicolidae). J exp mar Biol Ecol 136:197-216

Tugwell S, Branch GM (1992) Effect of herbivore gut surfactant on kelp polyphenol defences. Ecology 73: $205-215$

Wolfinbarger L Jr, Crosby MP (1983) A convenient procedure for radiolabeling detritus with ${ }^{14} \mathrm{C}$ dimethylsulfate. $J$ exp mar Biol Ecol 67:185-198

Manuscript first received: March 23, 1994

Revised version accepted: May 17, 1995 